\title{
COMPARISON THEOREMS BETWEEN SEVERAL QUASI-ARITHMETIC MEANS
}

\author{
Shoshana Abramovich, Josip PeČArić AND SANJA VAROŠANEC
}

Abstract. Comparison between quasi-arithmetic means are established by which we prove Jensen's type inequalities.

Mathematics subject classification (2000): 26A51, 26B25, 26D07, 26D15, $26 \mathrm{D} 20$.

Key words and phrases: Convex and concave functions, inequalities, means, Quasi-Arithmetic means.

\section{REFERENCES}

[1] S. Abramovich, J. E. PeČARIĆ, Convex and Concave Functions and Generalized Hölder Inequalities, Soochow Journal of Mathematics, Taiwan, 14 (1998), pp. 261-272.

[2] Young -Ho KIM, Refinements and extension of an Inequality, Journal of Mathematical Analysis and Applications 245, 628-632 (2000).

[3] D. S. Mitrinović, J. E. PeČARIĆ AND A. M. FinK, Classical and New Inequalities in Analysis, Kluwer Academic, Dordrecht/Boston/London, 1993. 